\title{
PENGEMBANGAN BAHAN AJAR PENDIDIKAN MATEMATIKA I UNTUK MENINGKATKAN KUALITAS PEMBELAJARAN MAHASISWA PGSD UNIVERSITAS KUNINGAN
}

\author{
Oleh: \\ Aan Nurhasanah ${ }^{1}$ \\ Universitas Kuningan
}

\begin{abstract}
This research and development aims to produce teaching materials for improving the quality of learning of Elementary Teacher Education students of University of Kuningan especially on Mathematics Education I course. This research using Dick and Carey Research \& Development model. The research stages are (a) the stages of analysis performed on the curriculum, the needs of the students and the lecturers' needs. (B) the product development stage is a lecture module, which is analyzed by expert team. $(C)$ the pilot stage, this stage is done if the expert team has finished validating the teaching materials to be used in the lecture process. The results showed that the teaching materials developed can improve the quality of learning with the average achievement of pre-test of 65.76 while the mean post-test value of 78.20 . Then the results of the observer assessment showed that $78 \%$ of students follow the course activities well.
\end{abstract}

Keywords: teaching materials, quality of learning, mathematics education

\begin{abstract}
Abstrak: Penelitian dan pengembangan ini bertujuan menghasilkan bahan ajar untuk peningkatan kualitas pembelajaran mahasiswa PGSD Universitas Kuningan khususnya pada matakuliah Pendidikan Matematika I. Metode penelitian yang digunakan adalah model Dick and Carey. Tahapan penelitian terdiri dari (a) tahapan analisis yang dilakukan terhadap kurikulum, kebutuhan mahasiswa serta kebutuhan dosen. (b) tahapan pengembangan produk berupa modul perkuliahan, yang dianalisis oleh tim ahli. (c) tahapan uji coba, tahapan ini dilakukan jika tim ahli telah selesai memvalidasi bahan ajar yang akan digunakan dalam proses perkuliahan. Hasil penelitian menunjukkan bahwa bahan ajar yang dikembangkan dapat meningkatkan kualitas pembelajaran dengan rerata pencapaian pretes sebesar 65,76 sedangkan rerata nilai postes sebesar 78,20. Kemudian hasil penilaian observer menunjukan $78 \%$ mahasiswa mengikuti aktivitas perkuliahan dengan baik.
\end{abstract}

Kata kunci : bahan ajar, kualitas pembelajaran, pendidikan matematika

\section{PENDAHULUAN}

Mata kuliah Pendidikan

Matematika I merupakan Mata Kuliah

Keilmuan dan Ketrampilan yang harus dipelajari dengan total 3 SKS oleh mahasiswa Program Studi PGSD. Mata kuliah ini merupakan mata kuliah dasar yang penting dikuasai mahasiswa sebagai calon guru SD, karena dalam mata kuliah ini dipelajari teknis penyampaian mata pelajaran matematika yang bersifat abstrak terhadap siswa SD yang secara kognitif masih tergolong pada tahapan oprasi kongkret.

Berdasarkan pengamatan penulis sebagian besar diperoleh keterangan bahwa dalam perkuliahan selama ini mahasiswa masih mengalami kesulitan, hal ini dikarenakan belum tersedianya bahan ajar yang praktis sebagai fasilitas PBM. Selama tiga tahun terakhir ini sumber yang digunakan berupa buku yang ada di perpustakaan saja, itupun jumlahnya terbatas. Selain itu beberapa kajian dari internet yang cakupan materinya sangat luas dan belum sesuai dengan silabus yang disampaikan dosen pengampu. Hal ini mengakibatkan rendahnya hasil belajar mahasiswa. Selain itu secara kognitif kemampuan mahasiswa masih berada di bawah standar. Hal ini terlihat dari

\footnotetext{
${ }^{1}$ Universitas Kuningan, Email: aannurhasanah9@gmail.com
} 
menurunnya prestasi mahasiswa dari setiap angkatan.

Agar mahasiswa mengalami kemudahan dalam mengenal dan memahami mata kuliah pendidikan matematika I, maka perlu disusun dan dikembangkan suatu perangkat pembelajaran yang dapat mengarahkan dan merangsang aktifitas berpikir mahasiswa dan dosen dalam menggali serta memaksimalkan kompetensi yang dimiliki mahasiswa, sehingga tujuan dari suatu proses pembelajaran dapat dicapai.

Pemilihan dan penggunaan perangkat pembelajaran yang tepat dalam suatu proses pembelajaran merupakan faktor yang sangat penting dalam mengarahkan mahasiswa untuk memperoleh pengalaman belajar. Cara dosen mengajar sangat terkait dengan penggunaan bahan ajar dan penyusunan SILABUS serta SAP yang tepat dan bagaimana mahasiswa belajar sangat terkait dengan penggunaan bahan ajar.

Berdasarkan permasalahan di atas maka perlu adanya pengembangan bahan ajar untuk mata kuliah pendidikan matematika I. Menurut Prastowo (2011) Bahan ajar merupakan bagian penting dalam pelaksanaan pendidikan, melalui bahan ajar guru atau dosen akan lebih mudah dalam melaksanakan pembelajaran dan mahasiswa akan lebih terbantu dan mudah dalam belajar. Bahan ajar yang peneliti kembangkan yaitu bahan ajar berupa buku. Bahan ajar ini diharapkan dapat mendukung proses pembelajaran Pendidikan Matematika SD I.

\section{TINJUAN PUSTAKA \\ Definisi Bahan Ajar}

Sebelum melaksanakan proses KBM setiap guru perlu mempersiapkan bahan ajar, bahan ajar adalah seperangkat sarana atau alat pembelajaran yang berisikan materi pembelajaran, metode, batasan-batasan dan cara mengevaluasi yang didesain secara sistematis dan menarik dalam rangka mencapai tujuan yang diharapkan, yaitu mencapai kompetensi atau subkompetensi dengan segala kompleksitasnya (Widodo dan Jasmadi dalam Lestari, 2013). Dengan demikian bahan ajar perlu didesain dan ditulis berdasarkan aturan intruksional sebab bahan ajar tidak hanya akan digunakanoleh pribadi namun akan digunakan pula oleh orang lain baik itu mahasiswa sebagai subjek pembelajaran atau guru/ dosen lain yang menjadi fasilitator KBM.

Bahan ajar yang dirancang seorang dosen akan sangat menentukan keberhasilan mahasiswanya, bahan ajar juga dapat dirancang dan disusun secara sistematis yang memungkinkan mahasiswa dapat belajar secara mandiri. Menurut Panen dan Purwanto (2001: 6) mengungkapkan bahwa bahan ajar merupakan bahan-bahan atau materi pelajaran yang disusun secara sistematis, yang digunakan guru dan peserta didik dalam proses pembelajaran. Dengan adanya bahan ajar, dosen akan lebih runtut dalam mengajarkan materi kepada mahasiswa dan tercapai semua kompetensi yang telah ditentukan sebelumnya.

\section{Fungsi Bahan Ajar}

Berdasarkan pengguna bahan ajar, fungsi bahan ajar dapat dibedakan menjadi dua, yaitu fungsi bahan ajar untuk tenaga pengajar dan fungsi bahan ajar untuk pembelajar atau mahasiswa.

Bagi tenaga pengajar bahan ajar mengubah peranan pengajar yang tadinya sebagai pendidik menjadi seorang fasilitator. Mahasiswa dapat belajar mandiri sesuai intruksi yang terdapat dalam bahan ajar, dosen sebagai fasilitator yang membimbing dan mengarahkan semua aktivitasnya dalam proses pembelajaran untuk mengikuti intruksi bahan ajar sehingga kegiatan pembelajaran lebih efaktif dan interaktif melalui proses diskusi. Bahan ajar juga dapat berfungsi sebagai alat evaluasi pencapaian atau penguasaan hasil pembelajaran. Menurut Prastowo (dalam Lestari, 2011) bahan ajar yang baik sekurang-kurangnya mencakup petunjuk belajar, kompetensi yang akan dicapai, isi 
pelajaran, informasi pendukung, latihanlatihan, petunjuk kerja, evaluasi dan respon terhadap hasil evaluasi. Dengan mengerjakan latihan dosen dapat lagsung menilai siswa setiap selesai perkuliahan.

Bagi pembelajar bahan ajar berfungsi sebagai media pembelajaran yang membantu mahasiswa untuk dapat belajar mandiri tanpa adanya batasan waktu pertemuan tatap muka langsung dengan dosen yang bersangkutan. Pemahaman mahasiswa tidak dibatasi oleh lamanya dia mengikuti perkuliahan tatap muka, dan setiap mahasiswa dapat belajar sesuai kemampuannya masing-masing. Bahan ajar dijadikan sebagai pedoman oleh mahasiswa, yang akan mengarahkan semua aktivitasnya dalam proses pembelajaran dan merupakan subtansi kompetensi yang seharusnya dipelajari dan dikuasainya.

\section{METODOLOGI PENELITIAN}

Peneliti menggunakan metode penelitian dan pengembangan atau disebut juga Research and Development, karena laporan yang dihasilkan peneliti berupa produk bagan ajar. Seperti pendapat Sugiyono (2011: 407) bahwa metode Penelitian dan Pengembangan adalah metode penelitian yang digunakan untuk menghasilkan produk tertentu, dan menguji keefektifan produk tersebut. Dengan menggunakan metode ini peneliti berharap dapat menghasilkan bahan ajar yang efektif. Sedikit berbeda dengan pendapat di atas, Sujadi (2003: 164) mengemukakan bahwa Penelitian dan Pengembangan atau Research and Development atau lebih dikenal dengan metode penelitian $R \& D$ adalah suatu proses atau langkah-langkah untuk mengembangkan suatu produk baru, atau menyempurnakan produk yang telah ada, yang dapat dipertanggungjawabkan. Produk yang dikembangkan dapat berupa buku, modul, media pembelajaran ataupun perangkat pembelajaran berupa software.

Adapun produk yang dikembangkan peneliti adalah bahan ajar mata kuliah Pendidikan Matematika SD I, yang akan digunakan dalam proses perkuliahan di PGSD.

Tahapan kegiatan penelitian yang dilaksanakan adalah hasil modivikasi dari tahap kegiatan yang disampaikan oleh Borg dan Gall, yaitu: (1) tahap analisis, kegiatan analisis yang dilakuakn peneliti terdiri dari kegiatan analisis pada kurikulum, kebutuhan mahasiswa, kebutuhan dosen serta karakteristik mahasiswa. (2) tahap pengembanagan, yang terdiri dari kegiatan pada pengembanagn bahan ajar yaitu berupa pengembangan modul pendidikan matematika SD I serta kegiatan penyusunan instrumen penelitian. Instrumen penelitian berupa seperangkat tes isian, skala sikap mahasiswa, dan lembar observasi aktivitas mahasiswa dalam mengikuti proses pembelajaran Pendidikan Matematika SD I. Dalam kegiatan penyusunan instrumen ini langkah yang dilakukan adalah menyusun lembar observasi pembelajaran, validasi bahan ajar dan validasi instrumen penelitian. (3) tahap uji coba bahan ajar, kegiatan yang dilakukan diantaranya adalah: (a) memberikan prites untuk mengetahui kemampuan awal mahasiswa; (b) peneliti melaksanakan pembelajaran Pendidikan Matematika SD I dengan bahan ajar yang telah dikembangkan; (c) mengobservasi kegitan pembelajaran yang sedang berlangsung. Pada kegiatan ini peneliti dibantu oleh dua orang observer; (d) memberikan angket kepada mahsiswa untuk melihat sikap mereka terhadap kegiatan pembelajaran menggunakan bahan ajar Pendidikan Matematika SD I yang telah dikembangkan. Setelah empat tahap analisis data, tahap ini merupakan tahap pengkajian data hasil observasi dan dan uji coba, sehingga menjadi sebuah deskripsi. (4) penulisan laporan hasil penelitian, tahap ini merupakan penyusunan dan penulisan deskripsi hasil penelitian. 


\section{HASIL PENELITIAN DAN PEMBAHASAN}

\section{Hasil Pengembangan Bahan Ajar}

Pada bagian ini diuraikan hasil penelitian pada setiap tahap pengembangan bahan ajar Pendidikan Matematika SD I. Model pengembangan perangkat pembelajaran yang digunakan mengacu pada model pengembangan Prosedural Borg dan Gall yang terdiri dari tiga tahapan yaitu analisis, pengembangan dan uji coba untuk pematangan bahan ajar.

\section{Tahap Analisis}

Pada tahap ini dilakukan analisis terhadap kurikulum, kebutuhan mahasiswa, kebutuhan dosen dan analisis media/ sumber belajar. Berdasarkan hasil pengamatan awal dilakukan dengan menganalisis kebutuhan mahasiswa. peneliti memperoleh informasi sebagai berikut: (1) mahasiswa masih terbiasa belajar secara pasif, karena kegiatan pembelajaran yang dilakukan masih berpusat pada dosen. Dosen lebih banyak mengajar dikelas, menjelaskan dan menulis dipapan tulis. Mahasiswa hanya mencatat bahan yang ada dipapan tulis. (2) pembelajaran tidak didukung perangkat/ bahan ajar yang memadai. Umumnya mahasiswa tidak memiliki buku pegangan sebagai sumber belajar, mahasiswa hanya mengandalkan materi dari dosen ketika pembelajaran berlangsung. Meskipun ada juga mahasiswa yang mencari bahan dari internet namun belum sesuai dengan standar pembelajaran di Universitas Kuningan. (3) Hasil belajar mahasiswa masih tergolong rendah, hal ini terjadi mahasiswa tidak memiliki bahan kaijian untuk dipahami kembali di rumah.

Selanjutya analisis dilakukan terhadap kebutuhan dosen. Dari hasil wawancara yang dilakukan sebagian besar dosen pengampu mata kuliah Pendidikan Matematika I tidak memiliki bahan ajar yang tetap dan efektif yang mengakibatkan kurang maksimalnya hasil pembelajaran mahasiswa.

Berdasarkan hal di atas maka diperoleh asumsi bahwa : (1) Kegiatan perkuliahan masih menggunakan metode student center; (2) bahan ajar/ sumber yang digunakan sebagai pedoman perkuliahan masih diambil dari berbagai sumber dan belum menunjukan intisari dari materi perkuliahan (3) bahan ajar mempengaruhi peningkatan hasil belajar mahasiswa.

\section{Tahap Pengembangan}

Pada tahap ini dikembangkan bahan ajar Pendidikan Matematika SD I untuk meningkatkan hasil belajar mahasiswa. Bahan ajar yang dikembangkan berupa modul untuk membimbing dan mengarahkan mahasiswa dalam memahami konsep materi pendidikan matematika I. Struktur bahan ajar yang dikembangkan dapat dilihat pada tabel 1 berikut:

Tabel 1. Struktur Bahan Ajar Pendidikan Matematika I

\begin{tabular}{|c|l|l|}
\hline No & \multicolumn{1}{|c|}{ Bagian } & \multicolumn{1}{|c|}{ Isi } \\
\hline 1. & Cover & $\begin{array}{l}\text { Judul modul/ Bahan Ajar, } \\
\text { penyusun, logo, instansi, } \\
\text { nama instansi }\end{array}$ \\
\hline 2. & $\begin{array}{l}\text { Kata } \\
\text { Pengantar }\end{array}$ & $\begin{array}{l}\text { Tujuan penyususunan } \\
\text { bahan ajar, ucapan terima } \\
\text { kasih dan harapan, } \\
\text { manfaat dari bahan ajar }\end{array}$ \\
\hline 3. & $\begin{array}{l}\text { Kata } \\
\text { Pengantar }\end{array}$ & $\begin{array}{l}\text { Konten yang terdapat } \\
\text { dalam bahan ajar }\end{array}$ \\
\hline 4. & Daftar Isi & $\begin{array}{l}\text { Tata tertib pada } \\
\text { pelaksanaan } \\
\text { pembelajaran dan tata } \\
\text { cara pembelajaran }\end{array}$ \\
\hline 5. & Pendahuluan & $\begin{array}{l}\text { Pengenalan tentang } \\
\text { modul pendidikan } \\
\text { matematika I }\end{array}$ \\
\hline 6. & $\begin{array}{l}\text { Materi } \\
\text { Setiap } \\
\text { Pertemuan }\end{array}$ & $\begin{array}{l}\text { Teori Belajar dan } \\
\text { Pembelajaran } \\
\text { Matematika, Kurikulum } \\
\text { Matematika } \\
\text { Perencanaan } \\
\text { Pembelajaran } \\
\text { Matematika, } \\
\text { Pngembangan Bahan Ajar } \\
\text { LKS, Alat Peraga dan } \\
\text { Media Pembelajaran } \\
\text { Matematika, Permainan }\end{array}$ \\
\hline
\end{tabular}




\begin{tabular}{|c|l|l|}
\hline & & $\begin{array}{l}\text { Matematika, Teknologi } \\
\text { Dalam Pembelajaran } \\
\text { Matematika SD }\end{array}$ \\
\hline 7. & $\begin{array}{l}\text { Daftar } \\
\text { Pustaka }\end{array}$ & $\begin{array}{l}\text { Sumber rujukan dalam } \\
\text { menyusun bahan ajar }\end{array}$ \\
\hline
\end{tabular}

Bahan ajar yang dikembangkan mencakup enam sub judul yang memfasilitasi mahasiswa dalam pembelajaran Pendidikan matematika I. Berikut ini struktur isi pada setiap sub judul bahan ajar yang dikembangkan.

Tabel 2. Struktur Sub Judul Bahan Ajar Pendidikan Matematika I

\begin{tabular}{|l|l|l|}
\hline No & Bagian & Isi \\
\hline 1 & Judul & $\begin{array}{l}\text { Judul materi yang } \\
\text { akan dipelajari pada } \\
\text { setiap pertemuan }\end{array}$ \\
\hline 2 & $\begin{array}{l}\text { Tujuan } \\
\text { Pembelajaran }\end{array}$ & $\begin{array}{l}\text { Tujuan yang akan } \\
\text { diharapkan setelah } \\
\text { kegiatan } \\
\text { pembelajaran }\end{array}$ \\
\hline 3 & $\begin{array}{l}\text { Kompetensi } \\
\text { Dasar/ materi } \\
\text { pokok }\end{array}$ & $\begin{array}{l}\text { Konsep dasar materi } \\
\text { yang akan di pelajari }\end{array}$ \\
\hline 4 & $\begin{array}{l}\text { Metode } \\
\text { Pembelajaran/ } \\
\text { Prosedur } \\
\text { Kerja }\end{array}$ & $\begin{array}{l}\text { Langkah-langkah } \\
\text { kerja selama kegiatan } \\
\text { pembelajaran }\end{array}$ \\
\hline 5 & $\begin{array}{l}\text { Responsi/ } \\
\text { Latihan soal }\end{array}$ & $\begin{array}{l}\text { Tugas atau pengerjaan } \\
\text { soal-soal materi } \\
\text { Pendidikan } \\
\text { matematika I yang } \\
\text { diberikan Dosen }\end{array}$ \\
\hline
\end{tabular}

Selain pengembangan bahan ajar Pendidikan Matematika I, dalam penelitian ini juga dikembangkan skala sikap terhadap pemahaman mahasiswa serta observasi aktivitas mahasiswa pada setiap pertemuan.

\section{Tahap Uji Coba Pengembangan Bahan Ajar}

Fase ini dilakukan untuk mengetahui : (1) apakah instrumen penelitian (draft bahan ajar, skala angket mahasiswa dan lembar observasi kegiatan mahasiswa) yang telah disusun valid atau tidak, berdasarkan pertimbangan para ahli/ validator; (2) apakah instrumen penelitian (draft bahan ajar, skala angket mahasiswa dan lembar observasi kegiatan mahasiswa) yang valid tersebut dapat mencapai hasil yang sesuai dengan tujuan yang telah ditetapkan. Berikut adalah hasil pengembangan instrumen penelitian (draft bahan ajar, skala angket mahasiswa dan lembar observasi kegiatan mahasiswa) yang telah diperoleh pada tahap ini.

\section{Hasil Validasi dan Revisi Instrumen Penelitian}

Instrumen penelitian yang dikembagkan adalah draft bahan ajar, skala angket mahasiswa dan lembar observasi kegiatan mahasiswa dinilai oleh dua validator yang telah kompeten untuk menilai kelayakan dari instrumen. Hasil validasi pertama, validator memberikan masukan untuk merevisi instrumen penelitian yang dikembangkan. Kemudian peneliti mengganalisis kembali masukan dari validator dan merevisi instrumen penelitian. Hasil perbaikan yang telah dilakukan peneliti kemudian divalidasi kembali oleh validator. Kegiatan tersebut terus dilakukan hingga mendapat persetujuan validator untuk mengujicobakan insteumen penelitian atau dianggap bahwa istrumen telah valid. Secara keseluruhan hasil validasi dari para ahli terhadap instrumen penelitian diperoleh sebagai berikut.

Tabel 3. Rekavitulasi Nilai Validasi Bahan Ajar oleh Validator

\begin{tabular}{|c|c|c|c|c|c|c|}
\hline \multirow{2}{*}{ No } & \multirow{2}{*}{$\begin{array}{l}\text { Komponen } \\
\text { Bahan Ajar }\end{array}$} & \multicolumn{2}{|c|}{ Validator } & \multirow[t]{2}{*}{ Jumlah } & \multirow{2}{*}{ Presentase } & \multirow[t]{2}{*}{ Kriteria } \\
\hline & & 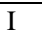 & II & & & \\
\hline 1 & $\begin{array}{l}\text { Komponen } \\
\text { Kelayakan } \\
\text { Isi }\end{array}$ & 38 & 42 & 80 & 72,72 & Baik \\
\hline 2 & $\begin{array}{l}\text { Komponen } \\
\text { Kebahasaan }\end{array}$ & 35 & 36 & 71 & 68,70 & Cukup \\
\hline 3 & $\begin{array}{l}\text { Komponen } \\
\text { Penyajian }\end{array}$ & 40 & 41 & 81 & 73,63 & Baik \\
\hline \multicolumn{5}{|c|}{ Rata-rata } & 71,68 & Baik \\
\hline
\end{tabular}

Berdasarkan hasil validasi diperoleh nilai rata-rata kualitas bahan ajar yang dikembangkan termasuk pada kategori baik. Berdasarkan indikator validasi bahan 
ajar maka bahan ajar yang dikembangkan dikatakan valid sehingga bahan ajar yang dikembangkan dapat diuji coba dilapangan.

Beberapa revisi yang dilakukan terhadap bahan ajar, skala sikap mahasiswa dan lembar observasi aktivitas mahasiswa dijabarkan sebagai berikut:

1) Bahan ajar Penilaian validator terhadap bahan ajar didasarkan pada indikator-indikator yang termuat dalam validasi bahan ajar. Pada umumnya hasil penilaian validator menyatakan bahan ajar baik dan dapat digunakan dengan sedikit revisi. Berdasarkan kesimpulan dan masukan dari validator, selanjutnya dilakukan revisi terhadap bahan ajar. Substansi yang direvisi meliputi kelayakan isi, kebahasaan dan konsep penyajian. Penjelasan lebih lengkap tentang revisi yang dilakukan terhadap bahan ajar dapat dilihat pada Tabel 4 berikut.

Tabel 4. Revisi Bahan Ajar Berdasarkan Masukan Validator

\begin{tabular}{|l|l|l|}
\hline No & Sebelum Revisi teori & Setelah Revisi \\
\hline 1. & $\begin{array}{l}\text { Pembahasan } \\
\text { pembelajaran belum } \\
\text { menyertakan contoh- } \\
\text { contoh real konsep } \\
\text { matematika di sekolah } \\
\text { dasar }\end{array}$ & $\begin{array}{l}\text { pembelajaran teori } \\
\text { telah } \\
\text { menyertakan rontoh real } \\
\text { konsep } \\
\text { matematika di } \\
\text { sekolah dasar }\end{array}$ \\
\hline 2. & $\begin{array}{l}\text { Pada beberapa latihan soal } \\
\text { terdapat kalimat yang } \\
\text { masih rancu sehingga } \\
\text { menafsirkan dua hal yang } \\
\text { berbeda }\end{array}$ & $\begin{array}{l}\text { Kalimat yang } \\
\text { masih rancu pada } \\
\text { bebera soal } \\
\text { latihan telah } \\
\text { direvisi }\end{array}$ \\
\hline 3. & $\begin{array}{l}\text { Masih terdapat kesalahan } \\
\text { dalam pengetikan }\end{array}$ & $\begin{array}{l}\text { Kesalahan dalam } \\
\text { pengetikan sudah } \\
\text { diperbaiki }\end{array}$ \\
\hline 4. & $\begin{array}{l}\text { Tampilan gambar tidak } \\
\text { jelas }\end{array}$ & $\begin{array}{l}\text { Tampilan gambar } \\
\text { di perjelas }\end{array}$ \\
\hline
\end{tabular}

\section{2) Skala Sikap Mahasiswa}

Penilaian validator terhadap skala sikap mahasiswa dalam pembelajaran Pendidikan Matematika I didasarkan pada kisi-kisi. Pada umumnya hasil penilaian validator menyatakan skala sikap mahasiswa dikatagorikan baik dan dapat digunakan dengan sedikit revisi. Berdasarkan kesimpulan dan masukan dari validator, selanjutnya dilakukan revisi terhadap skala sikap mahasiswa dalam pembelajaran Pendidikan Matematika I. Substansi yang direvisi meliputi tatabahasa.

3) Lembar Observasi Aktivitas Mahasiswa

Penilaian validator terhadap lembar observasi aktivitas aktivitas mahasiswa dalam pembelajaran Pendidikan matematika I didasarkan pada indikatorindikator. Pada umumnya hasil validasi menyatakan lembar observasi aktivitas mahasiswa dikatagorikan baik dan dapat digunakan dengan sedikit revisi. Bersadarkan revisi dan masukan dari validator, selanjutnya dilakukan revisi terhadap lembar observasi aktivitas mahasiswa dalam pembelajaran.

\section{Hasil Uji Coba Lapangan}

Bahan ajar yang telah direvisi berdasarkan masukan dari validator, kemudian diujicobakan kepada mahasiswa program studi PGSD Universitas Kuningan, tingkat I tahuan ajaran 2016-2017 supaya mendapat masukan-msaukan untuk menyempurnakan bahan ajar.

1. Hasil Uji Coba Kepraktisan

Bahan ajar Pendidikan Matematika I yang dikembangkan, divalidasi oleh dua tim ahli. Berdasarkan hasil validasi dari kedua validator mellalui langkah-langkah yang telah ditempuh dperoleh nilai rata-rata $75,23 \%$ dengan kriteria penilaian kategori baik. Sehingga bahan ajar yang dikembangkan dapat dikatakan valid. Secara umum kedua validator menyatakan bahan ajar yang dikembangkan baik sehingga dapat digunakan dengan sedikit perbaikan.

2. Hasil Pengamatan/ Observasi Aktivitas Mahasiswa

Kegiatan belajar mahasiswa dalam perkuliahan dikelas selama pembelajaran menggunakan bahan ajar Pendidikan Matematika SD I, diamati oleh dua orang observer. Hasil pengamatan dari setiap pertemuan kemudian direkap menjadi data 
hasil pengamatan/ observasi aktivitas mahasiswa dalam pembelajaran Pendidikan Matematika I yang tersaji dalam Tabel 5 berikut:

Tabel 5. Presentase Hasil Observasi Aktivitas Mahasiswa

\begin{tabular}{|c|l|c|c|c|c|c|c|}
\hline \multirow{2}{*}{ No } & \multicolumn{1}{|c|}{ Aspek yang dimati } & \multicolumn{5}{|c|}{ Penilainan Observasi } \\
\cline { 2 - 7 } & \multicolumn{1}{|c|}{ Setiap Pertemuan } \\
\hline 1 & $\begin{array}{l}\text { Mahasiswa hadir tepat waktu pada mata } \\
\text { kuliah Pendidikan Matematika I }\end{array}$ & $\mathrm{Y}$ & $\mathrm{T}$ & $\mathrm{Y}$ & $\mathrm{Y}$ & $\mathrm{T}$ & $\mathrm{Y}$ \\
\hline 2 & $\begin{array}{l}\text { Mahasiswa menunjukan keaktifan } \\
\text { dalam belajar }\end{array}$ & $\mathrm{T}$ & $\mathrm{Y}$ & $\mathrm{Y}$ & $\mathrm{T}$ & $\mathrm{Y}$ & $\mathrm{Y}$ \\
\hline 3 & $\begin{array}{l}\text { Mahasiswa memperhatikan penjelasan } \\
\text { dari dosen }\end{array}$ & $\mathrm{Y}$ & $\mathrm{Y}$ & $\mathrm{T}$ & $\mathrm{Y}$ & $\mathrm{Y}$ & $\mathrm{Y}$ \\
\hline 4 & $\begin{array}{l}\text { Mahasiswa membaca bahan ajar modul } \\
\text { dengan seksama }\end{array}$ & $\mathrm{Y}$ & $\mathrm{T}$ & $\mathrm{Y}$ & $\mathrm{Y}$ & $\mathrm{Y}$ & $\mathrm{Y}$ \\
\hline 5 & $\begin{array}{l}\text { Mahasiswa mampu menjawab dan } \\
\text { mengerjakan tugas yang diberikan } \\
\text { dosen }\end{array}$ & $\mathrm{T}$ & $\mathrm{Y}$ & $\mathrm{Y}$ & $\mathrm{Y}$ & $\mathrm{T}$ & $\mathrm{Y}$ \\
\hline 6 & $\begin{array}{l}\text { Mahasiswa membuat catatan untuk } \\
\text { mempermudah mengingat konsep } \\
\text { matematika }\end{array}$ & $\mathrm{Y}$ & $\mathrm{Y}$ & $\mathrm{T}$ & $\mathrm{Y}$ & $\mathrm{Y}$ & $\mathrm{Y}$ \\
\hline 7 & $\begin{array}{l}\text { Mahasiswa berkompetisi menyelesaikan } \\
\text { tugas dan mempresentasikannya } \\
\text { didalam kelas }\end{array}$ & $\mathrm{T}$ & $\mathrm{Y}$ & $\mathrm{Y}$ & $\mathrm{Y}$ & $\mathrm{Y}$ & $\mathrm{Y}$ \\
\hline 8 & $\begin{array}{l}\text { Bersisiplin dan semangat mengikuti } \\
\text { perkuliahan }\end{array}$ & $\mathrm{Y}$ & $\mathrm{Y}$ & $\mathrm{Y}$ & $\mathrm{T}$ & $\mathrm{Y}$ & $\mathrm{Y}$ \\
\hline 9 & $\begin{array}{l}\text { Mahasiswa fokus belajar selama } \\
\text { mengikuti perkuliahan }\end{array}$ & $\mathrm{Y}$ & $\mathrm{T}$ & $\mathrm{Y}$ & $\mathrm{Y}$ & $\mathrm{Y}$ & $\mathrm{Y}$ \\
\hline 10 & $\begin{array}{l}\text { Mahasiswa menyebutkan kembali serta } \\
\text { membuat kesimpulan }\end{array}$ & $\mathrm{Y}$ & $\mathrm{Y}$ & $\mathrm{Y}$ & $\mathrm{Y}$ & $\mathrm{Y}$ & $\mathrm{T}$ \\
\hline & Jumlah 'ya' & 7 & 7 & 8 & 8 & 8 & 9 \\
\hline & Presentasi aktivitas mahasiswa & 70 & 70 & 80 & 80 & 80 & 90 \\
\hline
\end{tabular}

Dari tabel di atas rata-rata aktivitas mahasiswa pada kegiatan pembelajaran dengan menggunakan bahan ajar Pendidikan Matematika SD I adalah $78 \%$ yang berarti aktivitas mahsiswa dalam mengikuti perkuliahan termasuk pada kriteria tinggi.

3. Hasil Skala Mahasiswa terhadap Pemahaman Konsep

Pemahaman konsep mahasiswa diukur menggunakan tes pemahaman, sedangkan untuk mengetahui sikap mahasiswa terhadap pembelajaran mata kulian Pendidikan Matematika I digunakan pengisian angket skala sikap yang dilakukan sebelum dan sesudah kegiatan pembelajaran.

Tabel berikut ini adalah menjelaskan hasil tes pemahaman mahasiswa sebelum dan sesudah mengunakan bahan ajar pendidikan matematika I.

Tabel 6. Nilai Pemahaman Konsep Mahasiswa

\begin{tabular}{|c|c|}
\hline Pemahaman Konsep & Nilai rata-rata \\
\hline Pretes & 65,76 \\
\hline Postes & 78,20 \\
\hline
\end{tabular}

Berdasarkan tabel di atas secara keseluruhan dapat dilihat bahwa rerata pemahaman konsep mahasiswa dalam pembelajaran mata kuliah "pendidikan matematika I" mengalami peningkatan, akan tetapi untuk mengetahui peningkatan kemampuan konsep dilakukan uji peningkatan menggunakan uji Gain (g). Hasil perolehan Gain (g) skor pemahaman mahasiswa secara umum dapat dilihat pada tabel 7 berikut.

Tabel 7. Hasil Perolehan Skor Pemahaman Konsep Mahasiswa

\begin{tabular}{|c|c|c|}
\hline Kriteria & $\begin{array}{c}\text { Jumlah } \\
\text { Mahasiswa }\end{array}$ & Presentase \\
\hline Rendah & 13 & $37,14 \%$ \\
\hline Sedang & 16 & $45,71 \%$ \\
\hline Tinggi & 6 & $17,14 \%$ \\
\hline
\end{tabular}

Berdasarkan tabel 7 terlihat bahwa hasil peningkatan kemampuan pemahaman konsep mahasiswa setelah menggunakan bahan ajar modul pendidikan matematika I diperoleh $37,14 \%$ untuk kriteria rendah, $45,71 \%$ untuk kriteria sedang dan $17,14 \%$ untuk kriteria tinggi.

Rata-rata klasikal skor Normalitas Gain dapat ditentukan berdasarkan rata-rata skor kemampuan pemahaman mahasiswa yang diukur berdasarkan sebelum dan sesudah pembelajaran dengan menggunakan bahan ajar modul pendidikan matematika I. Berdasarkan rerata skor kemampuan pemahaman konsep mahasiswa diperoleh data sebahai berikut:

rerata skor kemampuan pemahaman konsep sebelum pembelajarn $=65,76$ rerata skor kemampuan pemahaman konsep sebelum pembelajarn $=78,20$

Nilai maksimal 100

Maka rata-rata skor klasikal N-Gain adalah: $g=\frac{S_{\text {pos }}-S_{\text {pre }}}{S M I-S_{\text {pre }}}=\frac{78,20-65,76}{100-65,76}=0,36$

Secara rata-rata klasikal diperoleh nilai $\mathrm{N}$-Gain sebesar 0,36 yang berarti bahwa kemampuan pemahaman mahasisa termasuk kedalam kategori sedang. 


\section{KESIMPULAN}

Berdasarkan hasil penelitian maka dapat diperoleh kesimpulan sebagai berikut:

1. Bahan ajar yang dikembangkan berupa modul mata kuliah "Pendidikan Matematika I" telah memenuhi kriteria valid dan praktis yang terlihat dari rerata rekafitulasi hasil penilaian tim validasi yang diperoleh $71,68 \%$ dengan kriteria baik. Sehingga bahan ajar dapat digunakan dalam prodes perkuliahan.

2. Secara umun bahan ajar modul "Pendidikan Matematika I" dapat meningkatkan kualitas pembelajaran mahasisa PGSD Universitas Kuningan. Hal tersebut dapat terlihat dari hasil observasi aktifitas mahasiswa. Dalam setiap kesempatan mahsiswa datang tepat tepat waktu, sangat antusias dengan setiap kegiatan, aktif dalam menjawab pertanyaan dan mengajukan pendapat. Berdasarkan hasil penilaian dari observer $78 \%$ mahasiswa mengikuti perkuliahan dengan baik.

3. Perkuliahan dengan menggunakan modul "Pendidikan Matematika I" dapat meningkatkan hasil belajar. Hal tersebut terlihat dari hasil perolehan nliai rerata pretes yang diperoleh yaitu 65,76 dan rerata nilai postes sebesar 78,20. Secara rinci berdasarkan $\mathrm{N}$-Gain peningkatan tersebut terbagi kedalam tiga bagian yaitu peningkatan kemampuan pemahaman konsep sebesar $37,14 \%$ pada kategori rendah, $45,71 \%$ pada kategori sedang dan $17,14 \%$ pada katagori tinggi. Dan selanjutnya rerata $\mathrm{N}$-gain peningkatan tersebut berada pada tingkatan 0,36. Artinya secara keseluruhan dapat disimpulkan bahwa peningkatan kemampuan pemahaman mahasiswa berada pada tahap sedang.

\section{DAFTAR PUSTAKA}

Depdiknas. 2006. Standar Isi. Jakarta: Permendiknas 22 tahun 2006.

Lestari, Ika. (2013). Pengembangan bahan Ajar Berbasis Kompetensi: Sesuai dengan Kurikulum Tingkat satuan
Pendidikan. Padang: Akademia Permata.

Musfiqon. (2012). Metodologi Penelitian Pendidikan. Jakarta: Prestasi Pustakarya.

Pannen, Paulina dan Purwanto. (2001). Penulisan Bahan Ajar. Jakarta: Pusat antar Universitas untuk Peningkatan dan Pengembangan Aktivitas Intruktional Ditjen Dikti Diknas.

Prastowo, Andi. (2012). Panduan Kreatif Membuat Bahan Ajar Inovatif: Menciptakan Metode Pembelajaran yang Menarik dan Menyenangkan. Jogjakarta: DIVA Press

Sugiyono. (2011). Metode Penelitian Kuantitatif, Kualitatif, dan R \& D. Bandung: Alfabeta.

Sujadi (2003:164). Metode Penelitian Pendidikan. Jakarta: Rineka Cipta. 